\title{
Determining the Effects of High Intensity Ultrasound on the Reduction of Microbes in Milk and Orange Juice Using Response Surface Methodology
}

\author{
Balasubramanian Ganesan, ${ }^{1}$ Silvana Martini, ${ }^{2}$ Jonathan Solorio, ${ }^{2}$ and Marie K. Walsh ${ }^{2}$ \\ ${ }^{1}$ Western Dairy Center, Utah State University, 8700 Old Main Hill, Logan, UT 84322-8700, USA \\ ${ }^{2}$ Department of Nutrition, Dietetics, and Food Sciences, Utah State University, 8700 Old Main Hill, Logan, UT 84322-8700, USA \\ Correspondence should be addressed to Marie K. Walsh; marie.walsh@usu.edu
}

Received 19 February 2015; Accepted 1 May 2015

Academic Editor: Carl J. Schaschke

Copyright ( 2015 Balasubramanian Ganesan et al. This is an open access article distributed under the Creative Commons Attribution License, which permits unrestricted use, distribution, and reproduction in any medium, provided the original work is properly cited.

\begin{abstract}
This study investigated the effects of high intensity ultrasound (temperature, amplitude, and time) on the inactivation of indigenous bacteria in pasteurized milk, Bacillus atrophaeus spores inoculated into sterile milk, and Saccharomyces cerevisiae inoculated into sterile orange juice using response surface methodology. The variables investigated were sonication temperature (range from 0 to $84^{\circ} \mathrm{C}$ ), amplitude (range from 0 to $216 \mu \mathrm{m}$ ), and time (range from 0.17 to $5 \mathrm{~min}$ ) on the response, $\log$ microbe reduction. Data were analyzed by statistical analysis system software and three models were developed, each for bacteria, spore, and yeast reduction. Regression analysis identified sonication temperature and amplitude to be significant variables on microbe reduction. Optimization of the inactivation of microbes was found to be at $84.8^{\circ} \mathrm{C}, 216 \mu \mathrm{m}$ amplitude, and $5.8 \mathrm{~min}$. In addition, the predicted log reductions of microbes at common processing conditions $\left(72^{\circ} \mathrm{C}\right.$ for $\left.20 \mathrm{sec}\right)$ using $216 \mu \mathrm{m}$ amplitude were computed. The experimental responses for bacteria, spore, and yeast reductions fell within the predicted levels, confirming the accuracy of the models.
\end{abstract}

\section{Introduction}

High intensity ultrasound (HIU) waves (also known as power ultrasound; intensity $>1 \mathrm{~W} / \mathrm{cm}^{2}$, frequency $20 \mathrm{kHz}$ ) generate acoustic cavitation, where micro gas bubbles grow and implode to generate localized hot spots and increased pressure. The conditions within these collapsing bubbles generate localized temperatures exceeding $5,500^{\circ} \mathrm{C}$ and pressures of up to $50 \mathrm{MPa}[1,2]$. The bubble collapse results in a radiation of shockwaves that damages bacterial cell walls and cellular structural and functional components such as DNA by intracellular cavitation $[1,2]$. Ultrasound is commonly used in food processing for emulsification, controlling the viscosity of food systems, and improving cleaning and flux during ultrafiltration and microfiltration $[1,2]$.

Numerous studies have demonstrated the effective reduction of bacterial cells via ultrasound combined with heat treatment (thermosonication) in milk [3-5] and bacteria and yeasts in fruit juices [6-9]. Ultrasound application inactivates
Escherichia coli and Listeria $\left(85 \mathrm{~W} / \mathrm{cm}^{2}, 35^{\circ} \mathrm{C}\right)[10]$ at a slower rate in whole and skim milk versus buffer, which suggests that different matrices influence bacterial reduction. Thermosonication $\left(50^{\circ} \mathrm{C}\right)$ was synergistically more effective than ultrasound alone for the inactivation of E. coli and Staphylococcus epidermidis $\left(60 \mathrm{~W}, 50^{\circ} \mathrm{C}\right)$ in human milk [3]. Thermosonication $\left(63^{\circ} \mathrm{C}\right.$ for $\left.0-30 \mathrm{~min}\right)$ improved the shelf life of whole milk $[4,5]$ by reducing the number of mesophilic bacteria demonstrating its potential in improving milk quality and safety. Other studies have shown reductions in E. coli, Salmonella enteritidis, and the yeast Saccharomyces cerevisiae and Pichia fermentans in fruit juices (mango, grape, orange, and tomato) with the application of thermosonication $[6,7$, 9 , 11]. Many studies focused on the reduction of vegetative bacteria that are killed by pasteurization, whereas there is less information on the effects of thermosonication on thermo/mesophilic bacteria and spore reduction in foods.

Belgrader et al. [12] showed the disruption of Bacillus subtilis spores in a minisonicator using power levels from 
TABLE 1: The response surface experimental design and results for the log reductions of bacteria and spores in milk and yeast in orange juice.

\begin{tabular}{|c|c|c|c|c|c|c|c|c|}
\hline Run & $\begin{array}{l}\text { Time } \\
(\mathrm{min})\end{array}$ & Temp. $\left({ }^{\circ} \mathrm{C}\right)$ & $\begin{array}{l}\text { Amplitude } \\
(\mu \mathrm{m})\end{array}$ & $\begin{array}{c}\text { Actual log } \\
\text { reduction } \\
\text { bacteria }\end{array}$ & $\begin{array}{c}\text { Actual log } \\
\text { reduction } \\
\text { spores }\end{array}$ & $\begin{array}{l}\text { Actual } \log \\
\text { reduction yeast }\end{array}$ & $\begin{array}{l}\text { Acoustic power } \\
\text { in milk (W) }\end{array}$ & $\begin{array}{l}\text { Acoustic power } \\
\text { in juice }(\mathrm{W})\end{array}$ \\
\hline 1 & 3 & 41 & 216 & 3.37 & 1.89 & 3.4 & 6.19 & 5.82 \\
\hline 2 & 3 & 41 & 0 & 0.64 & 0.01 & 0 & 0 & 0 \\
\hline 3 & 1 & 10 & 180 & 0.49 & 1.00 & 0 & 11.12 & 10.59 \\
\hline 4 & 5 & 10 & 180 & 0.45 & 1.05 & 0 & 4.41 & 4.54 \\
\hline 5 & 1 & 72 & 180 & 3.04 & 1.34 & 5.85 & 10.40 & 10.82 \\
\hline 6 & 5 & 72 & 180 & 4.28 & 1.60 & 5.85 & 2.59 & 2.39 \\
\hline 7 & 5 & 41 & 36 & 1.26 & 1.20 & 0.10 & 1.03 & 1.00 \\
\hline 8 & 0.17 & 41 & 36 & 0.45 & 0.56 & 0.20 & 10.22 & 7.35 \\
\hline 9 & 3 & 84 & 36 & 7.76 & 1.80 & 5.90 & 0.64 & 0.71 \\
\hline 10 & 3 & 0 & 36 & 0.48 & 0.10 & 0 & 0.68 & 1.08 \\
\hline 11 & 3 & 41 & 108 & 0.53 & 0.50 & 0.40 & 3.05 & 2.90 \\
\hline
\end{tabular}

40 to $60 \mathrm{~W}$ for $2 \mathrm{~min}$. Also, $>99 \%$ disruption of Bacillus globigii spores was achieved with the same conditions in a continuous-flow system in microliter volumes [13]. These studies demonstrated that spore disruption is possible on a small scale with sonication, but optimization of conditions is necessary for large-scale use.

Based on previous studies, sonication temperature, amplitude, and time are the key parameters for microbial reduction in liquid systems. This study used response surface methodology (RSM) to optimize conditions of temperature, amplitude, and sonication time for maximum microbial reduction of bacteria and spores in milk and yeast in orange juice by determining the significant variables and creating predictive models for microbe reduction. RSM offers a large amount of information from a small number of experiments and it is possible to observe the interaction effects of the independent variables on the response. RSM also allows predictive responses for processing conditions (temperature and time) that have industrial importance. A sonication process that is amenable to the current industrial temperature and time processing conditions, such as pasteurization, is more likely to gain recognition and acceptance due to less infrastructural costs in modifying the processing equipment.

The purpose of this study was to determine the effects of sonication temperature, amplitude, and time on the inactivation of indigenous bacteria in pasteurized milk, Bacillus atrophaeus spores inoculated into sterile milk, and Saccharomyces cerevisiae inoculated into sterile orange juice. Data were analyzed by RSM and significant variables were determined. Predictive models for microbe inactivation were created and the suitability of the models was verified by comparing experimental optimal and realistic conditions to the predicted model.

\section{Materials and Methods}

2.1. Sources of Milk and Juice. Pasteurized skim milk was obtained from Rosehill Dairy (Hyrum, UT) and the Gary Haight Richardson Dairy Products Laboratory at Utah State
University (Logan, UT). Shelf stable orange juice was purchased locally (Minute Maid brand). For studying spore reduction, ultrahigh temperature-treated skim milk (UHT milk) was obtained from Gossner Foods (Logan, UT).

2.2. Microbial Growth. Pasteurized milk (initial cell count was $10^{2} \mathrm{CFU} / \mathrm{mL}$ ) was held at room temperature for $24 \mathrm{~h}$ to achieve a level of approximately $7 \times 10^{7} \mathrm{CFU} / \mathrm{mL}$ indigenous thermophilic microbes. Total aerobic bacteria from untreated or sonicated milk samples were enumerated on tryptic soy agar plates at $30^{\circ} \mathrm{C}$ for $24-48 \mathrm{~h}$. For spore samples, UHT milk was inoculated with $10^{5}$ Bacillus atrophaeus spores $/ \mathrm{mL}$ (NAMSA, Northwood, OH). For studying yeast reduction in orange juice, Saccharomyces cerevisiae 1015 was obtained from Presque Isle Cultures (Erie, PA) and grown in potato dextrose broth at $30^{\circ} \mathrm{C}$ for $48-72 \mathrm{~h}$ prior to inoculation into sterile juice to achieve an initial level of approximately $10^{6} \mathrm{CFU} / \mathrm{mL}$. $S$. cerevisiae was enumerated from sonicated samples after plating on potato dextrose agar and incubating at $30^{\circ} \mathrm{C}$ for $48-72 \mathrm{~h}$.

2.3. Sonication Equipment and Conditions. Ultrasound treatment was done according to Martini et al. [14]. Briefly, $6 \mathrm{~mL}$ of milk or orange juice was sonicated in a doublewalled glass vessel connected to a water bath. An ultrasonic processor (Sonicator 3000, Misonix Inc., Farmingdale, NY) set at $500 \mathrm{~W}$ and $20 \mathrm{kHz}$ with a $3.2 \mathrm{~mm}$ titanium microtip was used. The sonication times, temperature, and amplitudes used are listed in Table 1. Overheating of samples during sonication was prevented by keeping the temperature in the sonication chamber constant using a water bath. The acoustic power obtained for each amplitude in each sample was calculated as described below.

2.4. Calculation of Acoustic Power. Acoustic power is determined by a calorimetric technique that measures the change in temperature in a known volume of sample at various ultrasonic amplitudes. Acoustic power delivered to the samples 
was calculated as described by Martini et al. [14] and Jambrak et al. [15], using the equation below:

$$
P=M \times C_{p} \times \frac{d T}{d t}
$$

where $P$ is the acoustic power $(\mathrm{W}), M$ is the mass of sonicated sample $(\mathrm{g}), C_{p}$ is the specific heat capacity of the medium at constant pressure $(\mathrm{J} / \mathrm{g} / \mathrm{K})$, and $d T / d t$ is the increase in temperature during sonication $(\mathrm{K} / \mathrm{min})$. The specific heat capacity of the milk and orange juice $\left(\mathrm{kJ} / \mathrm{kg}^{\circ} \mathrm{C}\right)$ used was determined by differential scanning calorimetry according to Martini et al. [14].

2.5. Experimental Design. To explore the effects of independent variables on the response, a RSM design (Roquemore R311A hybrid, SAS, 9.4, The SAS Institute, Cary, NC) with three variables ( $X_{1}=$ time (range from 0.17 to $5 \mathrm{~min}$ ), $X_{2}=$ temperature (range from 10 to $84^{\circ} \mathrm{C}$ ), and $X_{3}=$ sonication amplitude (range from 0 to $216 \mu \mathrm{m})$ ) was performed. The response variable was $\log _{10}$ reduction $\left(Y_{1}\right)$ of microbes compared to unsonicated controls. The design consisted of 11 experimental points (Table 1) that were conducted in duplicate. The coded values were low $(-1.4)$, central $(0)$, and high (1.4).

2.6. Statistical Analysis. The response surface regression (RSREG) procedure of statistical analysis was used to analyze the experimental data. Experimental data were fitted to a second-order polynomial model and regression coefficients were obtained. The generalized second-order polynomial model used in the response surface analysis is given below:

$$
Y=\beta_{0}+\sum_{i=1}^{3} \beta_{i} X_{i}+\sum_{i=1}^{3} \beta_{i i} X_{i}^{2}+\sum \sum_{i<j=1}^{3} \beta_{i j} X_{i} X_{j},
$$

where $\beta_{0}, \beta_{i}, \beta_{i i}$, and $\beta_{i j}$ are the regression coefficients for intercept, linear, quadratic, and interaction terms and $X_{i}$ and $X_{j}$ are the independent variables. Residual analysis was performed (box and scatter plots) and the identification of outliers and influential data points was done to confirm adequacy of the data. Validity of the polynomial model was tested with analysis of variance (ANOVA). The significances of all terms in the polynomial were judged statistically by computing the $F$-value at $p=0.05$. Lack-of-fit significance, as well as $R^{2}$, and adjusted $R^{2}$ were evaluated for model accuracy. The design software was used to generate response surface plots while holding a variable constant in the secondorder polynomial model while maximizing $Y_{1}$. The ridge max option was used to compute the estimated ridge of maximum response for increasing radii from the center of the original design. Canonical analysis was conducted to determine the overall shape of the curve and to determine which variables(s) were the most influential.

2.7. Verification of Model. The predicted model was used to determine the optimal conditions for microbial reduction as well as estimate microbial reduction at common food processing conditions $\left(72^{\circ} \mathrm{C}, 10 \mathrm{~s}, 20 \mathrm{~s}\right)$ with amplitude of $216 \mu \mathrm{m}$. Experimental microbial reduction was compared to the predicted model to assess the accuracy of the predicted models.
2.8. Microbial Identification. Microbial colonies were isolated by plating serial dilutions of milk samples on tryptic soy agar (incubated at $30^{\circ} \mathrm{C}$ for $48 \mathrm{~h}$ ) at two different times 3 months apart. From these plates, 10 colonies were randomly chosen for DNA-based identification. Briefly, bacterial colonies were grown in tryptic soy broth for $48 \mathrm{~h}$. After growth was visually confirmed, cells were collected by centrifugation $(12,000 \times \mathrm{g}$ for $2 \mathrm{~min}$ ) and DNA was extracted after physical lysis using glass beads and using phenol-chloroform-isoamyl alcohol extraction as described by Ganesan et al. [16]. The isolated DNA was further used for $16 \mathrm{~S}$ ribosomal gene amplification by PCR using bacterial 16S rRNA gene primers (16S rRNA forward AGAGTTTGATCCTGGCTCAG and 16S rRNA reverse ACGGCTACCTTGTTACGACTT; Integrated DNA Technologies, Coralville, IA) and using a 2X PCR MasterMix (Thermo Fisher Scientific Inc., Pittsburgh, PA). Each final reaction mixture contained the following: template DNA, 1-2 $\mathrm{g}$; $\mathrm{MgCl}_{2}, 2.5 \mathrm{mM}$; primers, $10 \mathrm{pmol}$; and each dNTP, $0.4 \mathrm{mM}$. The amplification reaction was performed on a GeneAmp PCR system 2400 thermal cycler (Perkin Elmer, Waltham, MA) with initial enzyme activation at $95^{\circ} \mathrm{C}$ for $3 \mathrm{~min}$, followed by 40 cycles of denaturation at $95^{\circ} \mathrm{C}$ for $30 \mathrm{~s}$, annealing at $50^{\circ} \mathrm{C}$ for $30 \mathrm{~s}$, and extension at $72^{\circ} \mathrm{C}$ for $1 \mathrm{~min}$. The resulting PCR product was purified using a commercial kit (QiaQuick PCR purification kit, Qiagen, Valencia, CA) and submitted to USU's Center for Integrated BioSystems for single gene sequencing. Sequence results were compared against NCBI's nonredundant public databases using NCBI's BLAST software to provide species identification, which was assigned at $\geq 97 \%$ sequence identity to the nearest known reference database hits $\left(E\right.$-value $\left.\leq 10^{5}\right)$.

\section{Results}

3.1. Statistical Analysis and Model Fitting. We investigated the effects of temperature, amplitude, and time on the inactivation of bacterial cells and spores in milk and yeast in orange juice using RSM. The log reductions of microbes with the treatments used are given in Table 1 . A regression analysis (Table 2) was done to fit the mathematical models to the experimental data and the significance of each coefficient was determined using the $F$-test and $p$ value. For bacterial reduction in milk, the significant variables, in order with the largest effect first, were temperature $\left(X_{2}\right)$, followed by $X_{2} * X_{2}$, amplitude $\left(X_{3}\right)$, and $X_{3} * X_{3}$. For spore reduction in milk, the significant variables, in order with the largest effect first, were, $X_{3}, X_{2}, X_{2} * X_{2}, X_{2} * X_{3}, X_{1}$ (time) $* X_{1}$, and $X_{1}$. For yeast reduction in orange juice, all variables without time were significant, with the largest effects consisting of $X_{2}, X_{3}, X_{2} *$ $X_{2}, X_{2} * X_{3}$, and $X_{3} * X_{3}$ sequentially. The results suggest that temperature and amplitude were highly significant for the reduction of microbes, while time was only significant with spore reduction. The greatest log reductions of indigenous bacteria and spores in skim milk and yeast in orange juice are seen at the highest temperature $\left(84.4^{\circ} \mathrm{C}\right)$, while low treatment conditions for temperature and amplitude lead to low log reductions (Table 1). The acoustic power is the actual power dissipated as heat in the treated system and varies based on the amplitudes used and the specific heat capacity of the 
TABLE 2: Estimated regression model of the relationship between response variable $\left(Y_{1}\right)$ and independent variables $\left(X_{1}, X_{2}\right.$, and $\left.X_{3}\right)$.

\begin{tabular}{|c|c|c|c|c|c|c|}
\hline & \multicolumn{2}{|c|}{ Bacteria in milk } & \multicolumn{2}{|c|}{ Spores in milk } & \multicolumn{2}{|c|}{ Yeasts in $\mathrm{OJ}$} \\
\hline & $F$-value & Prob. $>F$ & $F$-value & Prob. $>F$ & $F$-value & Prob. $>F$ \\
\hline$X_{1}=$ time & 3.84 & 0.0735 & 5.63 & 0.0352 & 0.18 & 0.6775 \\
\hline$X_{2}=$ temperature & 78.62 & 0.0001 & 53.58 & 0.0001 & 3622.7 & 0.0001 \\
\hline$X_{3}=$ amplitude & 9.50 & 0.0095 & 59.02 & 0.0001 & 692.53 & 0.0001 \\
\hline$X_{1} * X_{1}$ & 0.28 & 0.6034 & 8.15 & 0.0145 & 1.06 & 0.3241 \\
\hline$X_{1} * X_{2}$ & 0.46 & 0.5086 & 0.12 & 0.7315 & 0.00 & 1.0000 \\
\hline$X_{1} * X_{3}$ & 1.87 & 0.1961 & 2.09 & 0.1741 & 0.18 & 0.6775 \\
\hline$X_{2} * X_{2}$ & 13.24 & 0.0034 & 10.51 & 0.0070 & 627.98 & 0.0001 \\
\hline$X_{2} * X_{3}$ & 0.025 & 0.8776 & 9.40 & 0.0098 & 106.64 & 0.0001 \\
\hline$X_{3} * X_{3}$ & 6.75 & 0.0233 & 4.28 & 0.0607 & 81.85 & 0.0001 \\
\hline
\end{tabular}

$X_{1}=$ time $(\mathrm{min}), X_{2}=$ temperature $\left({ }^{\circ} \mathrm{C}\right), X_{3}=$ amplitude, and $Y_{1}=\log$ reduction.

TABLE 3: Analysis of variance for the response surface quadratic model for log reductions of microbes.

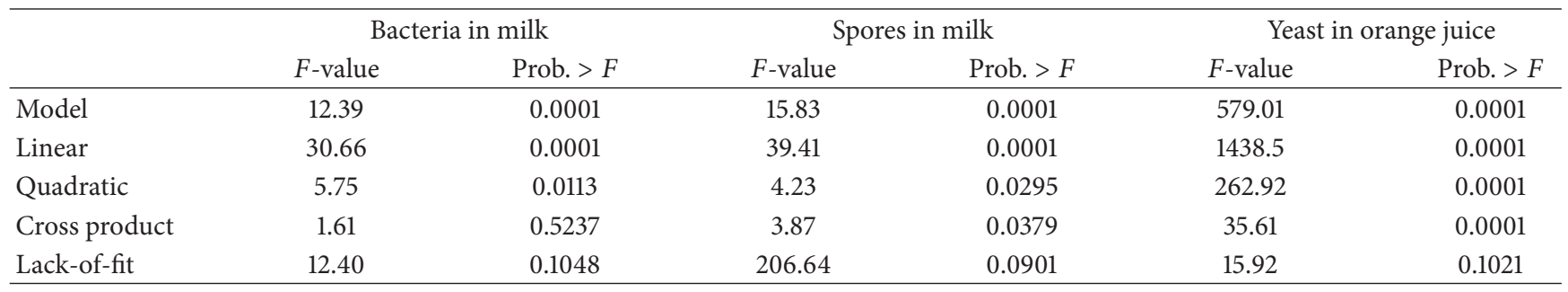

TABLE 4: The predicted mathematical models for bacteria, spore, and yeast reduction after ultrasound treatment.

\begin{tabular}{ll}
\hline Microorganism & Polynomial \\
\hline Bacteria in milk & $-0.85514-0.013031 * X_{2}-0.124421 * X_{3}+0.000553 * X_{2} * X_{2}+0.022416 * X_{3} * X_{3}$ \\
Spores in milk & $-0.13737-0.14663 * X_{1}+0.006844 * X_{2}+0.172535 * X_{3}+0.035885 * X_{1} * X_{1}+0.000182 * X_{2} * X_{2}-0.001798 * X_{2} * X_{3}$ \\
Yeast in orange juice & $0.491926+2.496654 * X_{2}+1.091597 * X_{3}+1.418168 * X_{2} * X_{2}+0.605779 * X_{2} * X_{3}+0.611709 * X_{3} * X_{3}$ \\
\hline
\end{tabular}

$X_{1}=$ time $(\mathrm{min}), X_{2}=$ temperature $\left({ }^{\circ} \mathrm{C}\right)$, and $X_{3}=$ amplitude.

liquid. The effects of acoustic power on microbe reduction are not obvious in Table 1 due to the different temperatures and times used for each sample.

Analysis of variance (ANOVA) for the models is given in Table 3. Hypothesis test on linear, quadratic, and cross product in ANOVA indicated that linear and quadratic regressions showed significant contribution to the models while cross product was also significant in the yeast and spore reduction models. The lack-of-fit error was insignificant for each model and the coefficients of determination $\left(R^{2}\right)$ for each predictive model (86.52, 87.24, and 99.66, resp., for bacteria, spores, and yeast) were adequate, suggesting a good fit. Thus the response was sufficiently explained by the models.

RSM allows the identification of optimum values of temperature, amplitude, and time to maximize the response $\left(Y_{1}\right.$ or $\log$ reduction). Three-dimensional response surfaces for the graphical representation of the regression equations are shown in Figure 1. In the plots, temperature and amplitude were developed for maximum log reduction $\left(Y_{1}\right)$ while time was held constant. This was based on the significance of the independent variables given in Table 2 . The maximum predicted log reductions were found at the highest temperature and amplitudes used. For spore reduction (Figure 1(b)) there was a linear increase in spore reduction with both an increase in temperature and amplitude, which agrees with the model analysis in Table 3. For yeast reduction (Figure 1(c)), temperature played a role higher than $40^{\circ} \mathrm{C}$, while there was a steady increase in log reduction of yeast with an increase in amplitude. Similarly, yet less dramatic effects are seen for bacterial reduction in milk (Figure 1(a)). The predictive mathematical models are given in Table 4. For each model, canonical analysis demonstrated a minimum point as the stationary point and of the three variables the most influential factor was temperature which is consistent with the regression analysis.

3.2. Verification of Models. The suitability of the model equations for predicting the optimal and realistic responses was tested and the data is shown in Table 5. Maximum microbe reduction for each was predicted at the highest temperature $\left(84.8^{\circ} \mathrm{C}\right)$ and amplitude $(216 \mu \mathrm{m})$ and longest sonication time (5.8 min) with predicted values of $15,2.29$, and $9.42 \mathrm{log}$ reductions each for bacteria, spores, and yeast. The actual log reduction for spores was within the predicted range. Since the initial cell counts of microbes in milk and orange juice were below the predicted log reduction, the data shown is the inactivation of all bacteria and yeasts in the samples. Foods are 


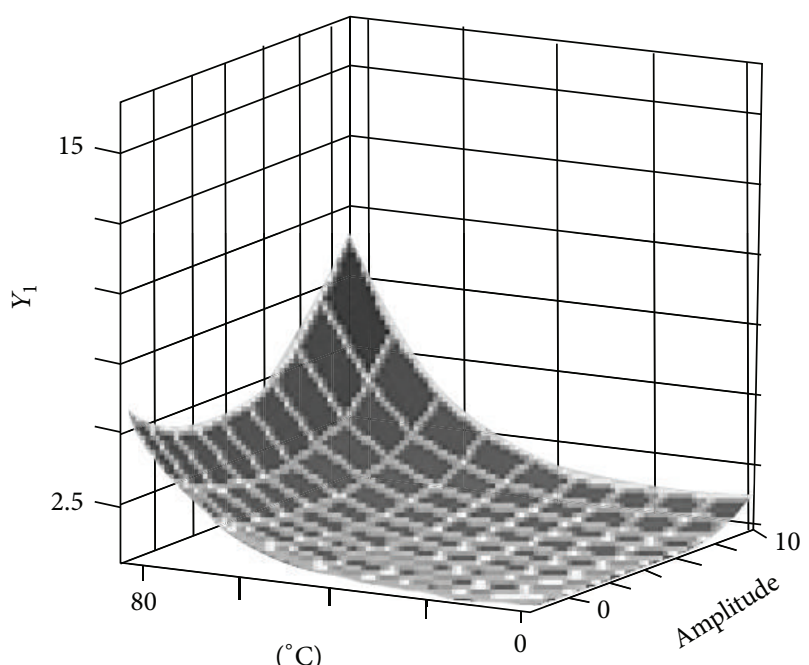

Fixed levels: $\min =3$

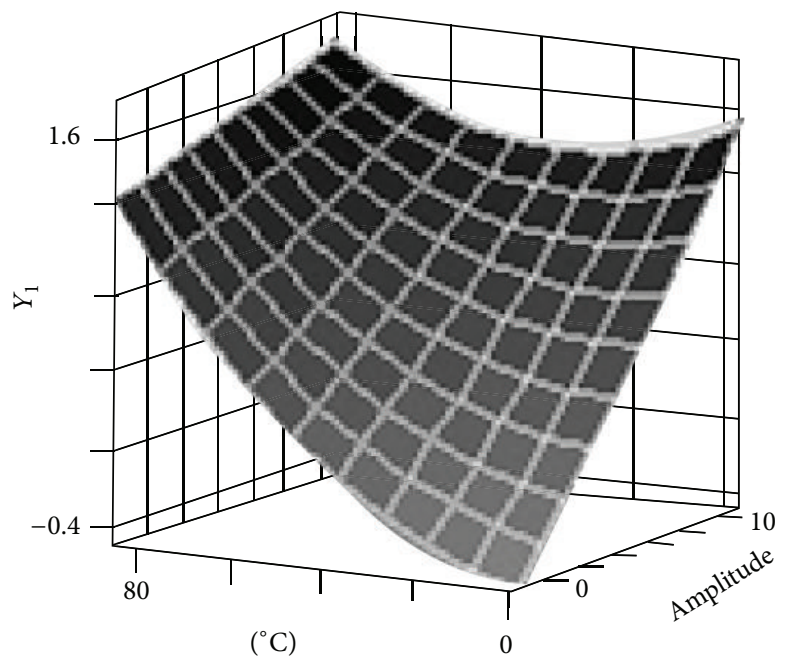

Fixed levels: $\min =3$

(a)

(b)

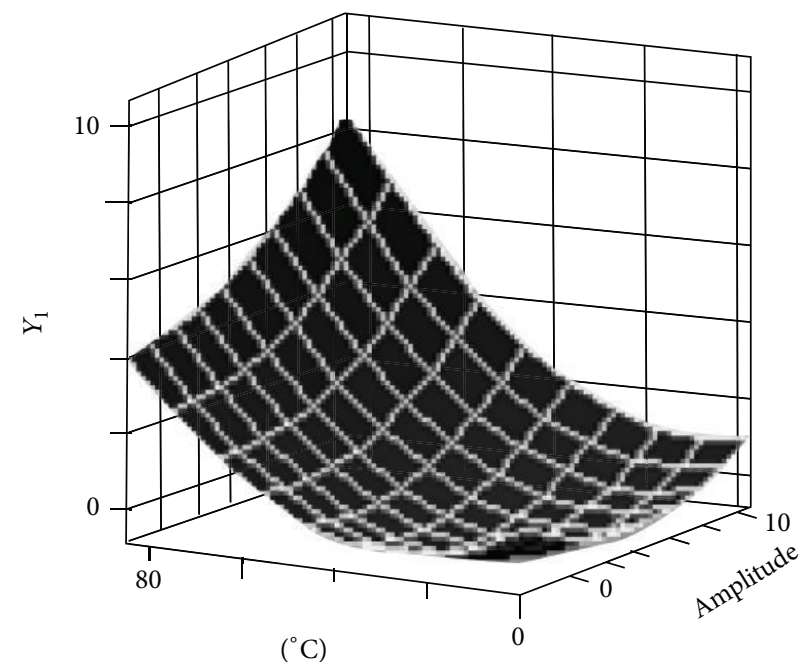

Fixed levels: $\min =3$

(c)

FIGURE 1: Response surface plots showing the optimization of sonication temperature and amplitude on the log reduction of indigenous bacteria $\left(Y_{1}\right)$ in milk (a), the log reduction of inoculated Bacillus atrophaeus spores $\left(Y_{1}\right)$ in milk (b), and the log reduction of inoculated $S$. cerevisiae $\left(Y_{1}\right)$ in orange juice $(\mathrm{c})$.

rarely processed above $75^{\circ} \mathrm{C}$; therefore, the realistic thermal processing conditions of $72^{\circ} \mathrm{C}$ and times of 10 and $20 \mathrm{sec}$ were used in the SAS response calculator to obtain predicted log reductions. As seen in Table 5, the actual log reductions fell within predicted levels for the realistic processing conditions. Doubling sonication time from 10 to 20 seconds did not increase the predicted bacteria and yeast counts because the sonication time effect was not significant in these models.

3.3. Microbial Identification. Ten random colonies from plated milk samples were selected for identification by $16 \mathrm{~S}$ rRNA gene sequencing. We found that the closest species matching the isolated colonies' DNA belonged to various species of bacteria such as Pseudomonas, Lactococcus,
Leuconostoc, Brochothrix, and unknown Enterobacteriaceae members. The presence of spore-forming bacteria was not detected by our approach.

\section{Discussion}

Thermophilic bacteria, yeasts, and spores can survive the current pasteurization of fruit juices and milk $[17,18]$. The presence of these microbes reduces product quality and shelf life due to production of acid, lipases, proteases, and offflavors during storage $[17,19]$. Additionally, the germination of spores is a concern in nonfat dry milk and skim milk powders because the powders themselves or food products 
TABLE 5: Comparison of the predicted and actual log microbial reductions in milk and juice attemperatures and times listed (all samples were run at $216 \mu \mathrm{m}$ amplitude).

\begin{tabular}{lccc}
\hline Time (min) & Temp. $\left({ }^{\circ} \mathrm{C}\right)$ & $\begin{array}{c}\text { Predicted log reduction } \\
\text { (range) }\end{array}$ & $\begin{array}{c}\text { Actual log } \\
\text { reduction }\end{array}$ \\
\hline & Indigenous thermophilic bacteria in milk \\
5.8 & 84.8 & $15(12.2,17.95)$ & $6.54^{1}$ \\
$0.17(10.2 \mathrm{sec})$ & 72 & $5.85(3.20,8.51)$ & 5.24 \\
$0.33(20 \mathrm{sec})$ & 72 & $5.85(3.24,8.47)$ & 5.39 \\
\hline \multicolumn{5}{c}{ Spores in milk } \\
5.8 & 84.8 & $2.29(1.52,3.07)$ \\
$0.17(10.2 \mathrm{sec})$ & 72 & $1.66(1.09,2.23)$ \\
$0.33(20 \mathrm{sec})$ & 72 & $1.68(1.17,2.11)$ & 2.01 \\
\hline & \multicolumn{3}{c}{ S. cerevisiae in orange juice } \\
5.8 & 84.8 & $9.42(9.12,9.72)$ & 1.56 \\
$0.17(10.2 \mathrm{sec})$ & 72 & $6.72(6.49,6.94)$ & $6.57^{1}$ \\
$0.33(20 \mathrm{sec})$ & 72 & $6.72(6.49,6.94)$ & $6.56^{1}$ \\
\hline
\end{tabular}

${ }^{1}$ The reduction represents the maximum amount of microbes in the sample.

formulated with them can have inferior quality and acceptability [17]. Pasteurization of milk and equivalent treatments for other liquid foods have been the most effective way of reducing microbial load while continuing to preserve freshness. Higher heat treatments such as ultrahigh temperature heating improve microbial quality at the expense of product freshness. Coupling ultrasound with pasteurization may aid in reducing the thermophilic microbes in fluid foods [19] extending the quality and shelf life of the products. Previous research has shown that no off-flavors were generated in $10 \%$ whey suspensions sonicated for $15 \mathrm{~min}$ using a power level of $3 \mathrm{~W}$; therefore product freshness should be retained in solicited milk [20]. Factors that affect the inactivation of microbes by ultrasound are the temperature of treatment, amplitude of the ultrasonic waves, the exposure time, the type of microorganism, the volume of food to be processed, and the composition of the food.

A recent study by Herceg et al. [21] used RSM to investigate the effects of temperature, amplitude, and sonication time on the inactivation of Staphylococcus aureus and E. coli in milk. They showed that temperature, time, and amplitude were significant for microbe inactivation. In this study, we showed that temperature had the greatest effect, followed by amplitude, on microbial reduction. Previous studies have shown that inactivation of bacteria and spores increases with the amplitude of the sonication waves $[22,23]$. The higher inactivation rate at greater amplitudes could be due to an increase in the number of bubbles undergoing cavitation [24].

This study showed that thermosonication was effective in reducing the bacterial load by at least 5 logs in milk at conditions of $72^{\circ} \mathrm{C}$ and $10 \mathrm{sec}$ and at an amplitude of $216 \mu \mathrm{m}$. Previous studies have also shown that there is a synergistic effect of heat and sonication $[3,5,6,21,25]$ on the reduction of bacteria. The listed studies used temperatures greater than $40^{\circ} \mathrm{C}$ and our data is in agreement that temperatures greater than approximately $40^{\circ} \mathrm{C}$ with sonication are effective for bacteria reduction. Herceg et al. [21] stated that the synergy between heat and ultrasound reduces at temperatures greater than $60^{\circ} \mathrm{C}$, turning into a cumulative effect.

There is conflicting data on the sensitivity of Grampositive and Gram-negative bacteria with some studies stating that they are affected equally, while others showed that either one or the other was more sensitive $[1,2,21]$, suggesting that either the Gram-positive bacterial cell wall or the Gramnegative bacterial cell membrane may be variably sensitive to ultrasound. We used indigenous bacteria present in pasteurized milk assuming they would be thermophiles. The identified bacteria in milk used here were both Gram-positive and Gram-negative and we did not determine whether there was differential reduction. Although these bacteria are not classified as thermophiles, they have been known to survive pasteurization conditions.

Studies on the inactivation of yeast in juices with sonication have shown a 7-log reduction of $S$. cerevisiae in grape juice at $60^{\circ} \mathrm{C}$ [7] and greater than a 5-log reduction of Pichia fermentans in tomato juice at $40^{\circ} \mathrm{C}$ [9]. Temperatures greater than $40^{\circ} \mathrm{C}$ were necessary for the inactivation of $S$. cerevisiae and the maximum inactivation of $S$. cerevisiae was observed at $60^{\circ} \mathrm{C}$. Valero et al. [26] showed a $0.6-\log$ reduction of indigenous yeast in orange juice at $88^{\circ} \mathrm{C}$ yet the conditions used by Khanal et al. [19] had no effect on indigenous yeasts $\left(10^{\circ} \mathrm{C}, 8 \mathrm{~min}\right.$, and $\left.89 \mu \mathrm{m}\right)$. Our results are in agreement in that temperatures greater than $40^{\circ} \mathrm{C}$ are needed for the inactivation of $S$. cerevisiae.

We showed a 1- to 2-log reduction of Bacillus spores at $72-85^{\circ} \mathrm{C}$, which is significant, considering that ultrahigh temperature treatment $\left(121-140^{\circ} \mathrm{C}\right)$ is the only established process for spore removal in milk in the food industry. Thermosonication is thus a viable approach for achieving microbial reduction greater than heat alone without going to ultrahigh processing temperatures. The design of an applicable process in pilot-scale fluid operations is a necessary step for confirming the benefits of thermosonication.

\section{Conclusion}

RSM was effective at estimating the effect of three independent variables on the log reduction of bacteria, spores, and yeast. Temperature and amplitude had highly significant effects on the response value as well as the quadratic of temperature. Optimum conditions for maximum log reduction were determined as well as the predicted log reductions as practical processing conditions. Experimental results were in the predicted ranges, verifying the accuracy of the models. Future research on verifying the accuracy of the models on a pilot scale using flow through thermosonication is necessary.

\section{Conflict of Interests}

The authors declare that there is no conflict of interests regarding the publication of this paper.

\section{Acknowledgment}

This project was partially funded by the Utah Agricultural Experiment Station and approved as journal paper number 8697. 


\section{References}

[1] J. Chandrapala, C. Oliver, S. Kentish, and M. Ashokkumar, "Ultrasonics in food processing-food quality assurance and food safety," Trends in Food Science \& Technology, vol. 26, no. 2, pp. 88-98, 2012.

[2] J. Chandrapala, C. Oliver, S. Kentish, and M. Ashokkumar, "Ultrasonics in food processing," Ultrasonics Sonochemistry, vol. 19, no. 5, pp. 975-983, 2012.

[3] C. Czank, K. Simmer, and P. E. Hartmann, "Simultaneous pasteurization and homogenization of human milk by combining heat and ultrasound: effect on milk quality," Journal of Dairy Research, vol. 77, no. 2, pp. 183-189, 2010.

[4] D. Bermúdez-Aguirre, M. G. Corradini, R. Mawson, and G. V. Barbosa-Cánovas, "Modeling the inactivation of Listeria innocua in raw whole milk treated under thermo-sonication," Innovative Food Science and Emerging Technologies, vol. 10, no. 2, pp. 172-178, 2009.

[5] D. Bermudez-Aguirre, R. Mawson, K. Versteeg, and G. V. Barbosa-Canovas, "Composition properties, physicochemical characteristics and shelf life of whole milk after thermal and thermo-sonication treatments," Journal of Food Quality, vol. 32, no. 3, pp. 283-302, 2009.

[6] W.-S. Kiang, R. Bhat, A. Rosma, and L.-H. Cheng, "Effects of thermosonication on the fate of Escherichia coli O157: H7 and Salmonella enteritidis in mango juice," Letters in Applied Microbiology, vol. 56, no. 4, pp. 251-257, 2013.

[7] D. Bermúdez-Aguirre and G. V. Barbosa-Cánovas, "Inactivation of Saccharomyces cerevisiae in pineapple, grape and cranberry juices under pulsed and continuous thermo-sonication treatments," Journal of Food Engineering, vol. 108, no. 3, pp. 383392, 2012.

[8] A. Muñoz, I. Palgan, F. Noci et al., "Combinations of high intensity light pulses and thermosonication for the inactivation of Escherichia coli in orange juice," Food Microbiology, vol. 28, no. 6, pp. 1200-1204, 2011.

[9] A. Adekunte, B. K. Tiwari, A. Scannell, P. J. Cullen, and C. O'Donnell, "Modelling of yeast inactivation in sonicated tomato juice," International Journal of Food Microbiology, vol. 137, no. 1, pp. 116-120, 2010.

[10] N. Gera and S. Doores, "Kinetics and mechanism of bacterial inactivation by ultrasound waves and sonoprotective effect of milk components," Journal of Food Science, vol. 76, no. 2, pp. M111-M119, 2011.

[11] C. D. Char, E. Mitilinaki, S. N. Guerrero, and S. M. Alzamora, "Use of high-intensity ultrasound and UV-C light to inactivate some microorganisms in fruit juices," Food and Bioprocess Technology, vol. 3, no. 6, pp. 797-803, 2010.

[12] P. Belgrader, D. Hansford, G. T. A. Kovacs et al., "A minisonicator to rapidly disrupt bacterial spores for DNA analysis," Analytical Chemistry, vol. 71, no. 19, pp. 4232-4236, 1999.

[13] D. P. Chandler, J. Brown, C. J. Bruckner-Lea et al., "Continuous spore disruption using radially focused, high-frequency ultrasound," Analytical Chemistry, vol. 73, no. 15, pp. 3784-3789, 2001.

[14] S. Martini, R. Potter, and M. K. Walsh, "Optimizing the use of power ultrasound to decrease turbidity in whey protein suspensions," Food Research International, vol. 43, no. 10, pp. 2444-2451, 2010.

[15] A. R. Jambrak, T. J. Mason, V. Lelas, Z. Herceg, and I. L. Herceg, "Effect of ultrasound treatment on solubility and foaming properties of whey protein suspensions," Journal of Food Engineering, vol. 86, no. 2, pp. 281-287, 2008.

[16] B. Ganesan, B. C. Weimer, J. Pinzon et al., "Probiotic bacteria survive in Cheddar cheese and modify populations of other lactic acid bacteria," Journal of Applied Microbiology, vol. 116, no. 6, pp. 1642-1656, 2014.

[17] S. A. Burgess, D. Lindsay, and S. H. Flint, "Thermophilic bacilli and their importance in dairy processing," International Journal of Food Microbiology, vol. 144, no. 2, pp. 215-225, 2010.

[18] C. E. Steyn, M. Cameron, and R. C. Witthuhn, "Occurrence of Alicyclobacillus in the fruit processing environment-a review," International Journal of Food Microbiology, vol. 147, no. 1, pp. 111, 2011.

[19] S. N. Khanal, S. Anand, K. Muthukumarappan, and M. Huegli, "Inactivation of thermoduric aerobic sporeformers in milk by ultrasonication," Food Control, vol. 37, no. 1, pp. 232-239, 2014.

[20] S. Martini and M. K. Walsh, "Sensory characteristics and functionality of sonicated whey," Food Research International, vol. 49, no. 2, pp. 694-701, 2012.

[21] Z. Herceg, A. R. Jambrak, V. Lelas, and S. M. Thagard, "The effect of high intensity ultrasound treatment on the amount of Staphylococcus aureusand Escherichia coli in milk," Food Technology and Biotechnology, vol. 50, no. 1, pp. 46-52, 2012.

[22] R. Pagán, P. Mañas, J. Raso, and S. Condón, "Bacterial resistance to ultrasonic waves under pressure at nonlethal (manosonication) and lethal (manothermosonication) temperatures," Applied and Environmental Microbiology, vol. 65, no. 1, pp. 297300, 1999.

[23] J. Raso, A. Palop, R. Pagán, and S. Condón, "Inactivation of Bacillus subtilis spores by combining ultrasonic waves under pressure and mild heat treatment," Journal of Applied Microbiology, vol. 85, no. 5, pp. 849-854, 1998.

[24] K. S. Suslick, “Sonochemistry," Science, vol. 247, no. 4949, pp. $1439-1445,1990$.

[25] M. Villamiel and P. de Jong, "Inactivation of Pseudomonas fluorescens and Streptococcus thermophilus in Trypticase Soy Broth and total bacteria in milk by continuous-flow ultrasonic treatment and conventional heating," Journal of Food Engineering, vol. 45, no. 3, pp. 171-179, 2000.

[26] M. Valero, N. Recrosio, D. Saura, N. Muñoz, N. Martí, and V. Lizama, "Effects of ultrasonic treatments in orange juice processing," Journal of Food Engineering, vol. 80, no. 2, pp. 509516, 2007. 

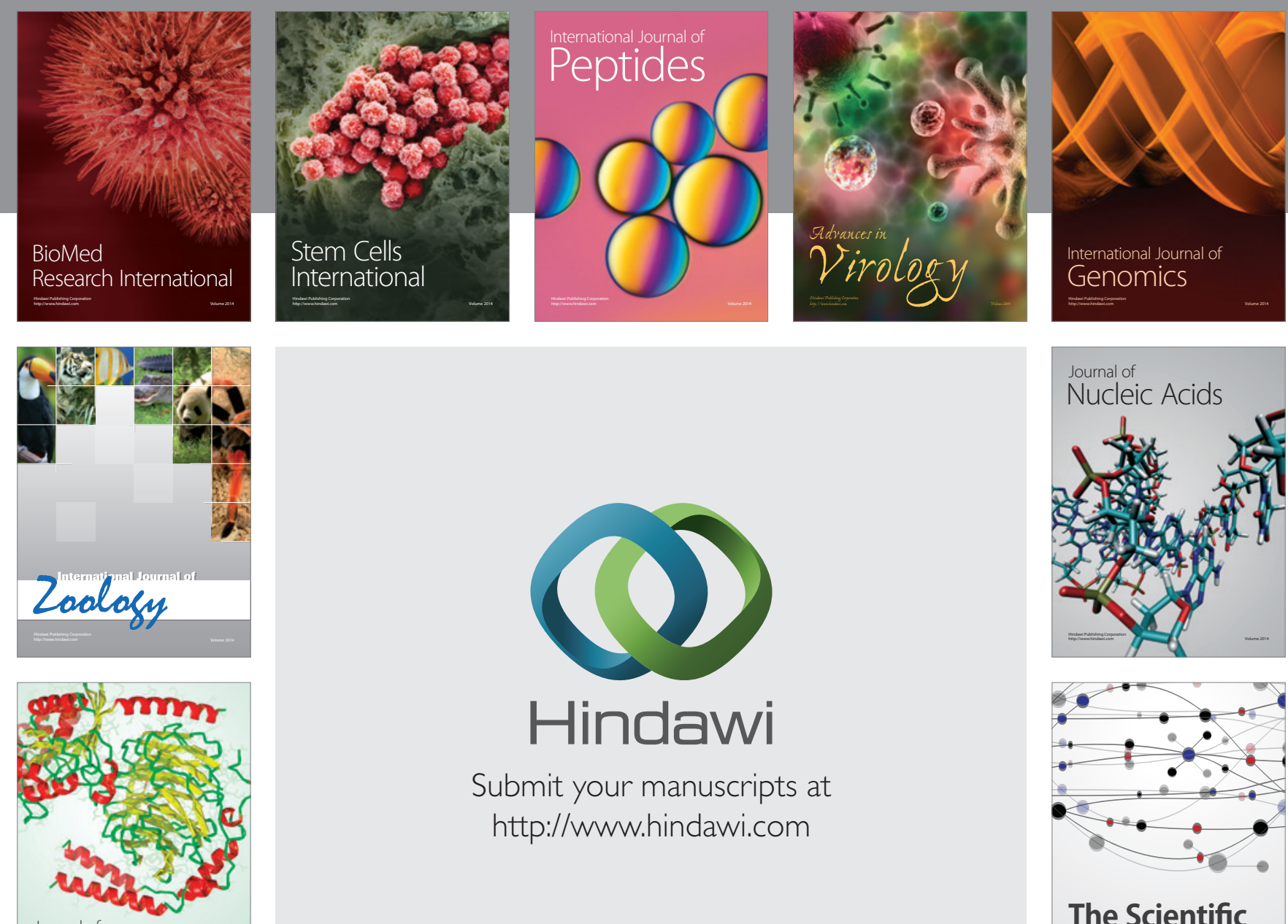

Submit your manuscripts at

http://www.hindawi.com

Journal of
Signal Transduction
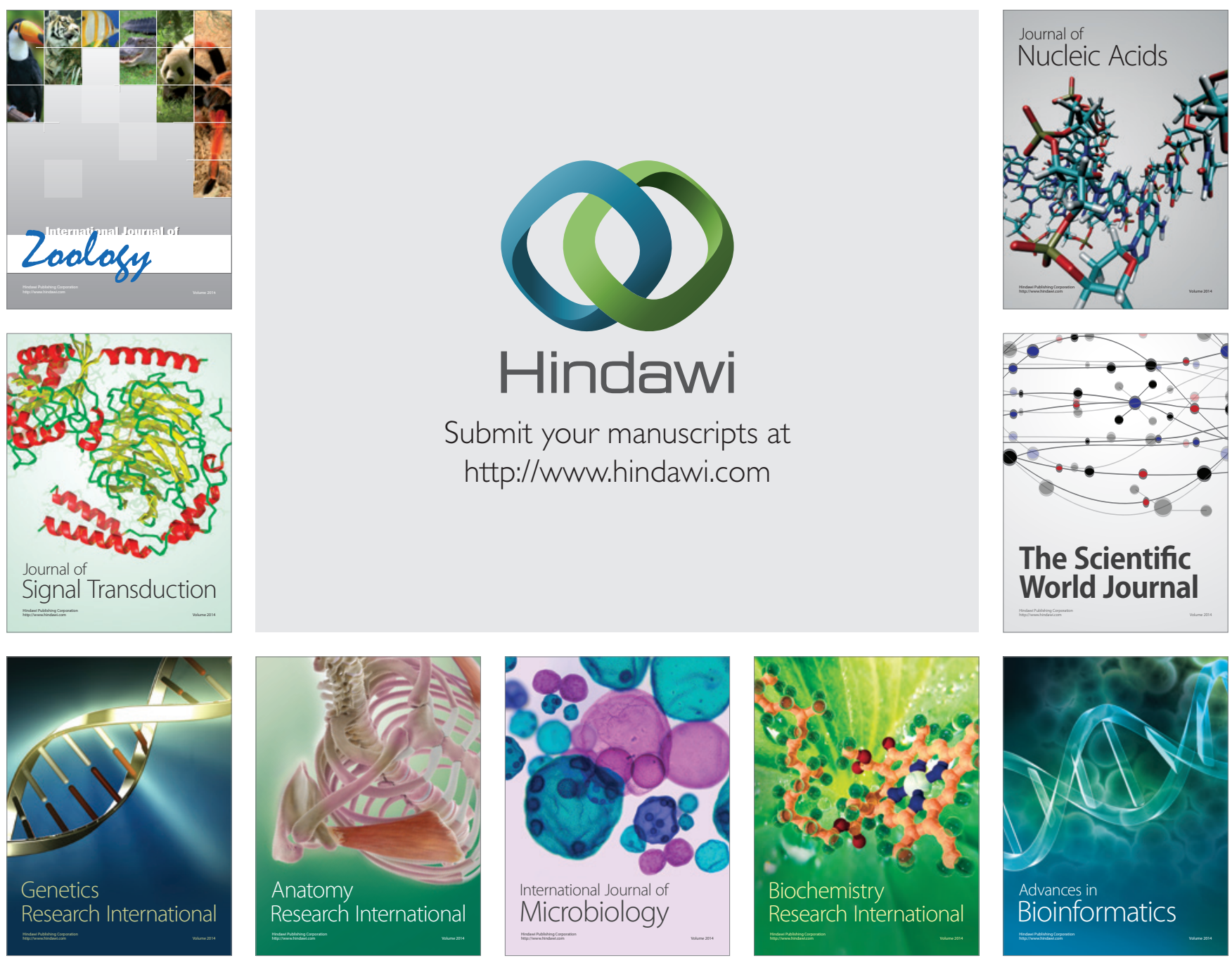

The Scientific World Journal
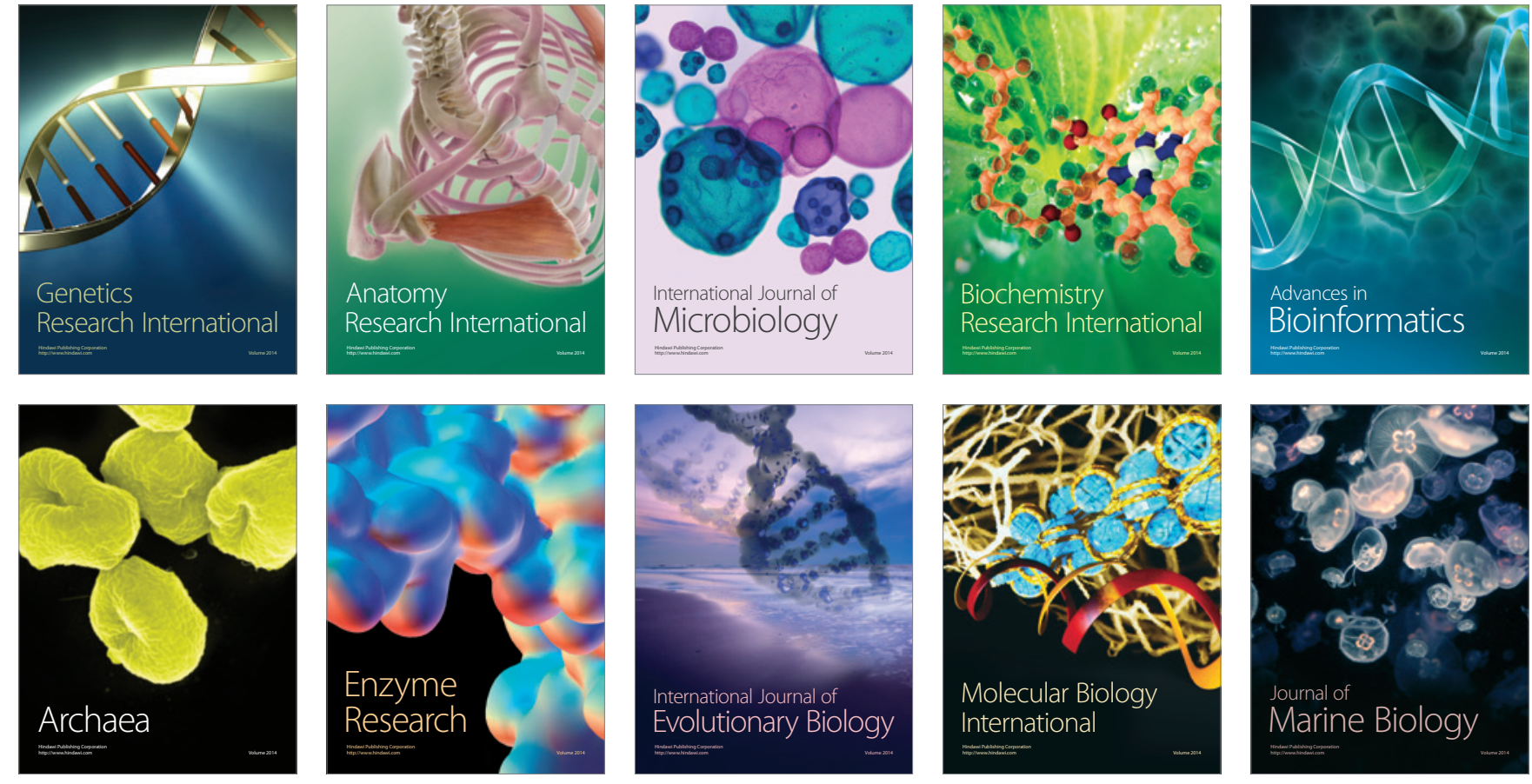